\title{
COLOR REVOLUTIONS: THEORY AND PRACTICE OF MODERN POLITICAL REGIMES DISMANTLING
}

\begin{abstract}
Аннотация. This paper analyses the problems connected with dismantling of political regimes in modern countries (both of authoritarian and democratic kind) that takes the form of colour revolutions. The role of state-organised party building in prevention of colour revolution and stabilisation of political situation is also considered. After the outbreak of the Arab Spring and the Ukrainian crisis, the problems mentioned have become acute and highly topical. In the world history there have always been place to dismantling of political regimes. In the past, however, it was performed through the use of force in its classical form, with the methods used during military takeovers, local military conflicts, civil wars, and military interventions. The global community succeeded in developing effective measures for combatting this threat and creating efficient mechanisms for political regulation at the international level. Though the severity of the problem connected with the threat of military takeovers in different countries is still on the agenda, the world community as a whole is familiar with this category of threats and knows how to counteract them.
\end{abstract}

Ключевые слова: Конфлитология, внешняя политика, США, мягкая сила, иветные револючии, демонтаж политических режимов, международный конфликт, международная стабильность, международная безопасность, международные отночения.

t the same time, the world is changing, and military takeovers are being replaced with subtler technologies of colour revolutions, which are craftily hiding under the guise of genuine revolutionary movements and hardly meet any opposition both on the part of developed democracies and on the part of the countries of the eastern type who have preserved the traditional way of life. The repetition of the colour-revolution scenario in Ukraine causes well-warranted concern, since it looks increasingly likely Ukraine being totally not the final stage of the scenario but a pawn in a geopolitical game, in which the attack planned by the US stage directors of colour revolutions may focus on Russia, China, and Kazakhstan.

The reasons behind the increased interest in the issue of colour revolutions lie in the fact that during the last three years a whole number of countries with quite stable political regimes had experienced coups d'état, leading to complete or partial dismantling of their political regimes which for many years had successfully resisted enemies from within and without: e.g. Egyptian, Tunisian, Syrian, and Libyan regimes had successfully opposed Islamism.

Moreover, the scenarios of regime change in these countries show a striking similarity, which can be interpreted as a recurring repetition of one and the same pattern or scheme, which reveals common features with the so called velvet revolutions that destroyed the communist regimes in the East of Europe after the collapse of the USSR.

This can hardly be regarded as purely accidental. The countries that suffered a regime change differ significantly in the level of political organisation of power, the level of social and economic development, and the range of unresolved problems. The possibility of an exact coincidence in scenarios in these countries is relatively, if not negligibly, small.

In this respect, Syria and Libya are intrinsically different from Ukraine and Georgia. It is easy to see, however, that the revolution of 2014 in Ukraine, which has become known as Euromaidan, coincides with the scenario of the Arab Spring revolution in Egypt, right down to the behaviour pattern of the fighting parties.

All this may be regarded as indicative of a situation when in two different counties and regions we deal with one and the same phenomenon: the results of employing the technologies of colour revolutions. However, despite the colourful name, there is nothing revolutionary about them. 
Even the western media today point out that colour revolutions, which are described as technologies of conducting operations aimed at exporting democracy through acts of civil disobedience, have by now become so sophisticated that their methods have turned into guidelines on changing political regimes ${ }^{1}$.

Colour revolutions are technologies for engineering a coup and controlling the political situation in the country from the outside, under conditions of induced political instability, with pressure on the government taking the form of political blackmail using youth protest movements as its tool. The aim of any colour revolution is a coup d'état, that is, seizing and retaining power by use of force. Despite the significant differences (geopolitical, social, economic and in international position) between the countries where these revolutions break out, they all fit into one and the same scheme that includes the pattern of organising youth protest movement, transforming this movement into a political crowd, and using this force against the existing government as an instrument of political blackmail. This is an explicit indication of the fact that colour revolutions cannot, by definition, be a means of fulfilling the dreams and desires of the popular majority.

Colour revolutions are not soft power; they are instruments used for destroying transitorytype democratic regimes, which were patterned after Anglo-Saxon models in non-western countries, bearing the sign of imitation. It would be fair to say that Americans not only created a model of the democratic state structure suitable for the purpose of exporting but also took the trouble to create special tools aimed at its destruction and dismantling, should the necessity arise. In modern world, such tools that serve as picklocks for breaking into political regimes of the liberal western kind are represented by the technologies of colour revolutions.

The aim of any colour revolution is a coup d'état, that is, seizing and retaining power by use of force.

For colour revolutions, the government and its relations are the objective, while the political regime is their target.

\footnotetext{
${ }^{1}$ Kara-Murza, S., Export of Revolution: Saakashvili, Yushchenko, and others, Moscow, 2005.
}

Colour revolutions have necessary and sufficient conditions for their successful implementation.

The necessary condition for engineering a colour revolution is political instability in the country, accompanied by the crisis of incumbent authorities. If political situation in the country is stable, it has to be destabilized artificially.

The sufficient condition is the existence of a specially organised youth protest movement (through a special network type of organisation).

Distinctive features of colour revolutions include the following:

- Colour revolutions affect the power in a specific way - through political blackmail;

- The main leverage against the government is the youth protest movement.

Colour revolutions only superficially resemble real revolutionary movements; unlike the true revolutions caused by the intrinsic factors of historical development, colour revolutions are technologies that misrepresent themselves as spontaneous processes. They are characterised by a theatrical level of «stage direction», which the western political analysts are trying to pass off as unplanned and spontaneous manifestations of the will of the people who suddenly decided to regain the right to rule their own country.

The engineered scenario of any colour revolution is based on Anglo-Saxon (North-American) philosophy of democratisation, designed for exporting democracy, democratic institutions, and values to contiguous countries ${ }^{2}$. Technologies of colour revolutions can only be put to practice successfully by their creators and developers, namely, the Anglo-Saxons. In any country where a colour revolution starts, one should look for a North-American imprint.

There are two explanations underlying the reasons behind colour revolutions: the theory of a spontaneous process and the theory of a staged process (accidental versus non-accidental). Both explanations can find their justification and neither is indisputable.

Advocates of the spontaneous theory claim that the reason behind colour revolutions is intrin-

\footnotetext{
${ }^{2}$ Hale, H.E, «Democracy or Autocracy on the March? The Colored Revolutions as Normal Dynamics of Patronal Presidentialism $\gg$, Communist and Post-Communist Studies, vol. 39, no. 3, 2006, pp. 305-329.
} 
sic social conflicts that manifest themselves in the form of popular uprisings and mass protest of the «oppressed» population. Among the causes they name poverty, weariness of the regime, desire for democratic change, and the demographic situation. At the same time, a detailed examination of social and political situation in practically any country where a colour revolution took place often reveals that conflicts and social divide existing there, while serving as a catalyst for subsequent events, were not the main or single reason behind them. In Egypt, for instance, there existed before the revolution the so called flatbread subsidies, which ensured affordability of the main staple, flatbread, for the poorest part of the population; in slum quarters of Cairo you can see a satellite dish on the roof of every shanty; in Libya citizens used to get natural resource royalties (as well as numerous other social benefits), which were so high that the country's population stopped working altogether, and the task of working was put on migrant workers, often from Egypt and other African countries; the standard of living in Tunisia, the most democratic of all authoritarian African countries, was very close to that of the south of France (Provence and Languedoc), while exceeding that of southern Italy; one of the reasons for the outbreak of protest movements in Syria was the decision taken by Assad (in absence of any pressure) to liberalize the authoritarian regime and start liberal reforms, which was immediately used to their advantage by the Islamists, their sponsors from the US, etc.

Advocates of the staged theory point at the recurring repetition of the same scenario (pattern) used for staging these revolutions in different countries of the world that differ significantly both in their political system and the character of their social and political problems. They argue that all colour revolutions are «carbon copies> of each other and that the possibility for an event to repeat itself in the same form and follow exactly the same pattern is almost non-existent in the real world. On the basis of these conclusions, advocates of the staged theory point at a number of features that allows for recognising a colour revolution in any outwardly spontaneous popular uprising.

Any colour revolution possesses characteristics that expose it as a technology.
First, a distinct Anglo-Saxon foreign-policy imprint, their unique working style.

Second, the plan of any colour revolution strictly follows the basic pattern (scenario); all colour revolutions develop in accordance with one and the same scenario that uses a single template.

Third, there are similarities in the manner of organising and exploiting the youth protest movement, which is controlled with the help of reflexive governance technologies (also an American invention).

Fourth, there are certain repetitive characteristics that are manifest in selection and nomination of revolutionary leaders.

Fifth, some colour revolutions totally lack any revolutionary ideology, which makes it possible to recognise a fake. This results from the fact that Americans, who are behind these colour revolutions, do not always understand the mentality and psychology of the people to whom they plan bringing «the values of true democracy» and cannot offer them an ideology that could be seamlessly embraced by all social strata.

Colour revolutions are often described as technologies and tools of soft power in Joseph Nye's understanding of the term ${ }^{1}$. This approach based on the analogy principle (in outward appearance, colour revolutions are soft power technologies of changing political regimes) is not entirely accurate and often misleading, making one believe that colour revolutions are a softer, and therefore more progressive and less socially dangerous, way of influencing authoritarian regimes. Hence, a campaign is started for promoting colour revolutions in opposition to any other forms of military takeovers. In our opinion, it would be hard to determine what in reality is more dangerous for international security as a whole: colour revolutions or local military conflicts. The modern Middle East plunged by colour revolutions into a «controlled » chaos is a highly representative example of that. Nevertheless, it seems rather obvious that modern colour revolutions are essentially not manifestations of soft power. Colour revolutions are nothing less than an organised form of political blackmail (i.e. blackmail targeting an independent sovereign

\footnotetext{
${ }^{1}$ Nye, Joseph S. Jr., Soft Power: The Means to Success in World Politics, New York, Public Affairs Group, 2004.
} 
state) hiding behind the legend and slogans of a national revolution.

Colour revolutions are not soft power; they are instruments for breaking democratic regimes of a transitory type, which were patterned after Anglo-Saxon models by non-western countries, carrying the sign of imitation. It would be fair to say that Americans not only created a model of democratic state structure geared for exporting it but also took the trouble to create special tools aimed at its destruction and dismantling, should the necessity arise. In modern world such tools that serve as a kind of picklock for breaking into political regimes of the liberal western kind are represented by the technologies of colour revolutions.

Special attention should be paid to the possible degeneration of a colour revolution into a civil war or an international conflict taking the character of an armed confrontation. Colour revolutions use the factor of military power as a support function, which is only foreseen by the authors of scenarios and technologies as used in case of emergency. For colour revolutions military power is not the main tool; its use can rather be characterised as forced and subordinate. Nonetheless, one cannot but notice an interesting fact that modern colour revolutions indeed create conditions and motives for subsequent military intervention.

The model underlying a colour revolution is always the same: creating a protest movement, transforming it into a political crowd, and directing its aggression towards the incumbent government with the aim of forcing it to resign voluntarily and to withdraw from ruling the country. The pressure put on the government always takes the form of blackmail, by issuing an ultimatum while threatening to start mass riots and, which is less frequent, threatening violence and physical attack against dissenters. If the authorities start to fight back, the colour revolution enters the phase of an armed rebellion. Sometimes this rebellion is accompanied by a military intervention on the part of the western countries, as it happened in Libya and may still happen in Syria.

The model of a colour revolution consists of five main stages or phases:

Any colour revolution starts with the establishment in the country of an organised protest movement — the main driving force of the future colour revolution.

During the first stage, prior to starting its overt action, the protest movement is organised in the form of a network consisting of secret cells, each including a leader and three or four active members serving as their liaison officers. Such networks unite thoUSnds of active members, constituting the core of the future protest movement. Many of the future protesters, prior to becoming leaders of such cells, are trained in special centres specialising in promoting democratisation.

Active members are recruited from among the young people, who are very impulsive and easily moved by flashy slogans and calls to action.

The network principle of protest movement organisation is similar to that of global terrorist networks; this is essentially one and the same organisational pattern.

The cells of the network emerge from the underground to the streets of large cities simultaneously and in response to a prearranged signal, which is called an incident. This can be any event that offends the community and causes public outrage. Typically, this incident is deliberately initiated.

For Revolutions in Serbia (Bulldozer Revolution of 2000), Ukraine (2004), and Georgia (2004), this incident was the results of elections that were declared to have been fixed. Revolution in Tunisia (2010), a country with an authoritarian regime, started with a vendor setting himself on fire in one of the squares in the city centre - an incident that in itself is rather small on the national scale.

It is important for the incident to attract the attention of everyone in the society and become a subject generating a wide discussion, interpretation, increased general agitation and spontaneous forms of mass behaviour.

After the incident takes place, the protest network emerges from the underground to the streets where the active cell members become catalysts of spontaneous mass processes that involve more and more people.

This sets in motion the mechanisms of conflict mobilisation, one of their manifestation being the so called twitter revolutions coordinated via social networking sites.

The cells soon start attracting citizens who get involved in the spontaneous protest move- 
ment, pushed into it mainly by the fear for their future. The general anxiety leads to the situation when people's consciousness enters the so called borderline state and becomes prone to mass panic reactions and collective hysteria, which often finds its expression at the levels of instincts and reflexes. Starting from that moment, there is but one step from transforming the protesting community into a crowd.

The next stage in the colour revolution scheme is the creation of a political crowd. For that purpose, a rather large square (maidan) is chosen that can accommodate a significant number of people.

The active members lead their protesting electorate to such a maidan, where during a many-hours-long meeting all participants merge into a single mass of people, which is described in psychology by the term «crowd». Full emotional merger of separate individuals into one crowd takes place, and this crowd starts using flashy «revolutionary» symbols for identifying friends and foes.

At this stage, the crowd is influenced with the help of technologies that affect people's subconscious, instil new values and imperatives, and reprogram the mind. These are the same technologies that are used in protestant totalitarian sects.

Conditions necessary for stable existence and functionality of the crowd are carefully maintained: material support, tents, hot food, clothes, money for the active members, offensive means (crowbars, etc.), and so on. There is also a wellorganised «logistics service».

In the name of the crowd, ultimatum demands are presented to the government, supported by threats of mass riots and - less frequently - of physical attack. If the regime cannot withstand the assault, it is swept away by the tide. If the regime takes up the challenge and shows determination to fight back, the crowd becomes the main battering-ram used by the creators of the colour revolution for attacking the government. From this point on, such a revolution is invariably transformed into a rebellion, and in certain cases - into a civil war, followed by a military intervention.

Evolution of organisational schemes and patterns used in colour revolutions can be well observed based on the example of Arab Spring revolutions. Specifically, Arab Sprig revolutions have their own features, distinguishing them both in structure and technology from their predecessors - colour revolutions in Central Asia, Ukraine, Georgia, and even the so called Green Revolution of 2009 in Iran: the classic colour revolution implementation pattern (i.e., a coup d'état) is supplemented with the feedback mechanism (the iteration mechanism well known to mathematicians) and the «controlled chaos mechanism that can be used to control political instability not only within one separate and relatively small country, such as Ukraine or Georgia, but throughout a whole region (the Middle East, North Africa, Central Asia, etc.).

The feedback mechanism is a special correction tool that provides for real-time identification of deficiencies in colour revolution patterns. It also provides immediate remedial action by modifying them to fit specific conditions of a particular sociocultural environment. This very mechanism was for the first time put into practice in the course of Arab Spring revolutions. The coups d'état in the countries falling victim to a wave of «involuntary democratisation» were mounted not simultaneously but one after another, in chain order, and every subsequent pattern took into account the mistakes made when implementing the previous pattern. Introduction of feedback mechanisms based on iteration schemes into the algorithms of colour revolutions is a direct result of their evolution, offering the possibility to immerse into the revolutionary process not only separate countries but whole regions.

The «controlled chaos mechanism is yet another evolutionary breakthrough in the technologies of colour revolutions. It allows for implementation of «democratic schemes and patterns initially developed for societies of the western (individualist) type in traditional eastern societies, which were initially resistant to the promotion of democratic and liberal values. In order for the western, Anglo-Saxon colour revolution technologies to work in this kind of sociocultural environment, it is necessary first to dismantle its traditional social patterns, and this is exactly what «controlled chaos> technologies do (and are quite successful at that). The main purpose of using these technologies is to prepare a traditional society for technologies of control over mass political consciousness 
and crowd behaviour, the goal achieved through the society's «atomisation», that is, by breaking ties between separate individuals and their community and instilling a surrogate individualism of the western type in people's minds.

Contemporary events in Ukraine (20132014) are also related to colour revolutions they duplicate the Egyptian scenario. Therefore, it can be expected that the colour revolution in Ukraine also opens a door for foreign intervention, as it was in Libya and is still possible in Syria.

Comparing the Ukrainian colour revolution 2.0 with recent events in the Middle East and North Africa, it should be pointed out that the scenario of the Ukrainian revolution 2014 exactly replicates the revolution in Egypt, where the regime of Hosni Mubarak was destroyed and the Egyptian president was removed from his office and imprisoned. There are too many exact similarities:

- for example, the very character of popular unrest degenerating into mass riots that were posed as spontaneous while being in reality nothing of the kind;

- and a well-organised protest movement backed up by paramilitary forces - Ukrainian nationalists that were redeployed to Kiev from western parts of Ukraine where they had been for years training their combat skills in special camps, studying the resistance tactics to be used against special police forces and the security service of Ukraine, as well as urban warfare tactics;

- besieging the government authorities and capturing strategic sites and sensitive facilities of the capital's infrastructure;

- using conflict mobilisation technologies, involving the population in the conflict on the side of the «representatives of the rebellious population'; inciting hatred against the ruling regime; employing large-scale ideological indoctrination of those who fell under the influence of the radicals;

- a large-scale information war;

- properly organised supply of the rebels with everything needed to continue the fight, including military-style operation gear, clothes, food, financial resources necessary to pay for services of mercenaries and agents provocateurs.

However, the similarities between Egyptian and Ukrainian revolutions do not end here: in both cases, under the guise of the rebellious population, well-armed and organised militant groups started their militant action; in Egypt these were the Islamists and in Ukraine - western nationalists. At the same time, the armed struggle, which had all the signs of a civil war, was still presented as «a national liberation movement started by the people revolting against a criminal government $\gg$.

In both cases «the rebellious people» were confronted by a weak, irresolute and corrupt authorities who were afraid of decisive actions; hesitated when faced with a choice to make; ran from one former ally to another, while the latter in the new situation were eager to distance themselves from the government; issued contradictory statements, thus demonstrating their own helplessness and discrediting themselves more efficiently than any attempts of their adversaries. This is exactly what Mubarak did: up to the very last moment, he continued to believe that the US would come and save him from the colour revolution that they themselves had staged, still hoped that this was just an educational measure. However, his hopes came to nothing, just like the expectations of Yanukovych that an almost European Ukraine was not the uncivilised Egypt and that Ukrainians were different from uneducated Arabs, and that the situation would take care of itself.

A few years after the Egyptian revolution, Yanukovych acted in exactly the same way as Mubarak: despite the obvious threat from the growing rebellion, which started with essentially insignificant disturbances on the maidan, he did nothing to curb the situation. Instead of taking strong though warranted measures and restoring the order (as Lukashenko did in the case of the «cornflower revolution'), Yanukovych started a strange political game, trying to ingratiate himself now with the West (the EU and the US), now with Russia, hoping that «faced with the great task of holding back the chaos», he will be able to obtain yet another disbursement of money from both. This weakness was the reason why Yanukovych first lost support of his electorate, and then was also abandoned by supporters who started actively ratting out or changing sides. Faced with this crisis, Yanukovych finally gave the order to suppress the maidan with force, but he did not have enough courage to carry it through; from the moment when the rebels deployed the illegal armed forces of the nationalists and started organizing «self-defence squads> from the main body 
of the protesters, supressing the rebellion was only possible at a high price in blood. However, Yanukovych could not bring himself to carry this out, not so much trying to avoid civilian casualties, but rather afraid to lose his money and accounts in foreign banks, for he could have been easily deprived of those if recognised as an «international criminal». His overtures to the EU also played their fatal role: the EU first insisted the Yanukovych should take firm measures to quell the unrest in the capital, restoring the rule of law and order, but when he finally started doing that and the first casualties appeared, the EU immediately started talking about violation of human rights and genocide by Yanukovych and his regime against their own people as well as about the need to make concessions to appease the rebels and initiate talks with them. When Yanukovych followed these recommendations and opened negotiations with the rebels, the latter regarded that as an acknowledgement by the government of its weakness and stepped up their activity, entering the phase of violent armed confrontation. As a result, Yanukovych and his team, instead of continuing the fight or taking the consequences of their actions, simply fled Kiev.

Differences between Egypt and Ukraine are in fact quite insignificant: in Egypt the Arabs took to the squares of Cairo, while in Kiev these were Ukrainian nationalists and ordinary citizens dissatisfied with the dominant position of the Donetsk clan. In both cases the people were «tired of the government $\gg-$ Mubarak's and Yanukovych's regimes - and this acted as a catalyst of the colour revolution. This is what the nationalists are trying to appeal to, forgetting the obvious resemblance between the Ukrainian and the Egyptian scenarios. In the course of similar revolutions in Syria and Libya, the government was confronted by Islamists against whom it had for many decades fought an uncompromising fight; among the nationalists in Ukraine there are many Catholics, Greek Catholics, and adherents of numerous Protestant sects that are predominantly totalitarian and preaching extremism. In both countries the success of the government overthrow became possible only due to the weakness and constant hesitations of the regime that was initially over-confident but very soon lost heart and, by its own actions, gave its supporters the run-for-your-lives signal. After the coup d'état in Egypt, the power was taken by mod- erate Islamists, while in Ukraine it was seized by ultranationalists, which is almost the same thing.

The repetition of the colour-revolution scenario in Ukraine in 2013-2014 causes well-warranted concern, since it looks increasingly likely that Ukraine is totally not the final stage of this scenario but a pawn in a geopolitical game, in which the attack planned by the US stage directors of colour revolutions may focus on Russia, China, and Kazakhstan.

It is interesting that there appear in some of the latest works of western scholars, including French and British ones, assessments of colour revolutions that contradict the views imposed by the United Stated that colour revolutions are instruments of democratisation and development of a democratic world. For instance, some scholars now begin to claim, though rather cautiously, that none of the colour revolutions in the Middle East or North Africa brought prosperity to the Christian world; quite the opposite, the Arab Spring stirred up and encouraged emergence from deep hiding of the most dangerous extremist forces representing Islamism, and the western countries now have to deal with them at the official level. The Arab Spring that started under the slogans of democratisation of the Arab East sped up the retreat of Christianity, which was pushed back by the onslaught of radical Islam, since after the start of the Arab Spring colour revolutions radical Islamism has dramatically increased in strength. The Arab Spring, paid for and supported by American and European allies, has turned into the beginning of the «Christian winter» for the Western Christian world, which was already in severe crisis ${ }^{1}$. The western Christianity had to yield yet another of its defensive positions. This makes one give serious thought to the role that colour revolutions really play today in the world politics and in the development of the new world order, and what this new world order is going to be like if the wave of colour revolutions is not stopped in good time.

Nevertheless, the modern world has at its disposal a framework of measures that can help to minimise the risk of colour revolutions and their development. It includes three groups of measures, with one containing the tools of stateorganised party building.

\footnotetext{
${ }^{1}$ Filiu, J. - P, The Arab Revolution. Ten Lessons from the Democratic Uprising, London, Hurst \&Co., 2011, p. 195.
} 
The first group of measures is aimed at uncovering and blocking the flow of funds used to finance the protest movement. The second group of measures is aimed at involving the social base of the protest movement - young people of 18 to 35 - into the work of pro-government civic organisations. The third group of measures includes creating in the society of certain «air release valves $>$ enabling people to let off steam and ease the tensions, not letting the society «to overheat» and release the built-up energy in the form of a social outburst. Creating such «valves is the main task of state-organised party building in response to the threat of colour revolutions.

The protest movement within colour revolutions is supported not only by the impassioned young people who have not yet been able to find their place in life; at its core are the active members of opposition parties and movements who are shut out of the parliament and who have no way left to them other than a revolution to make their political statement. Numerous screening and qualification requirements that impede their political activity within the common legal framework merely contribute to their further radicalisation and create an informal «shadow» political sector open to the ideas of colour revolutions. The policy of stateorganised party building should, in contrast, lead these movements out of the «shadow» sector and direct their activity into the official legal environment where they will be playing by the rules set by the government. The experience of western democracy that had for many years fought against separatism provides a good example of tools to be employed for persuading radicals to use exclusively legitimate methods of political struggle: ETA in Spain and the IRA in Britain, who abandoned the armed confrontation and effectively turned into political parties, are in this respect the most telling example.

\section{БИБАИОГРАФИЯ}

1. Kara-Murza, S., Export of Revolution: Saakashvili, Yushchenko, and others, Moscow, 2005.

2. Filiu, J. - P, The Arab Revolution. Ten Lessons from the Democratic Uprising, London, Hurst \&Co., 2011, p. 195.

3. Hale, H.E, «Democracy or Autocracy on the March? The Colored Revolutions as Normal Dynamics of Patronal Presidentialism», Communist and Post-Communist Studies, vol. 39, no. 3, 2006, pp. 305-329.

4. Nye, Joseph S. Jr., Soft Power: The Means to Success in World Politics, New York, Public Affairs Group, 2004.

5. Аемидов А.В. От «мягкой силы» к «управляемому хаосу»// Международные отношения. - 2014. - 2. - С. 230 - 236. DOI: 10.7256/2305-560Х.2014.2.10355.

6. О. Г. Карпович Миротворческие операции США и Европейского Союза и роль технологий управления межАународными конфциктами в подАержании мира // Политика и Общество. - 2012. - 1. - C. $108-118$.

\section{REFERENCES (TRANSLITERATED)}

1. Kara-Murza, S., Export of Revolution: Saakashvili, Yushchenko, and others, Moscow, 2005.

2. Filiu, J. - P, The Arab Revolution. Ten Lessons from the Democratic Uprising, London, Hurst \&Co., 2011, p. 195.

3. Hale, H.E, «Democracy or Autocracy on the March? The Colored Revolutions as Normal Dynamics of Patronal Presidentialism», Communist and Post-Communist Studies, vol. 39, no. 3, 2006, pp. 305-329.

4. Nye, Joseph S. Jr., Soft Power: The Means to Success in World Politics, New York, Public Affairs Group, 2004.

5. Demidov A. V. Ot «myagkoi sily»k «upravlyaemomu khaosu»// Mezhdunarodnye otnosheniya.-2014. - 2.- C. 230-236. DOI: 10.7256/2305-560X.2014.2.10355.

6. O.G. Karpovich Mirotvorcheskie operatsii SShA i Evropeiskogo Soyuza i rol» tekhnologii upravleniya mezhdunarodnymi konfliktami v podderzhanii mira // Politika i Obshchestvo.2012. - 1. - C. 108-118. 